\section{Dengue in Costa Rica: the gap in local scientific research}

\author{
Adriana Troyo, ${ }^{1,2}$ \\ Sherri L. Porcelain, ${ }^{1,3}$ \\ Olger Calderón-Arguedas, ${ }^{2}$ \\ Dave D. Chadee, ${ }^{4}$ \\ and John C. Beier ${ }^{1}$
}

Globalization has affected the reemergence of infectious diseases, with increased human travel and trade facilitating the introduction of diseases into new areas and the resurgence of diseases that had been eliminated in some places (1). However, the increased availability of scientific information from various research groups can help in the development of new and improved disease control measures. The combination of scientific research and reliable field assessments that consider different areas of knowledge and different geographic locations (world regions, countries, and communities) is essential for building greater understanding. This combination can also provide evidence that guides prevention and control measures at the local, national, regional, and global levels.

Dengue is a reemerging and uncontrolled disease. With dengue, there is a need for more scientific research on the local factors that affect the disease system and the relationships among those factors. There is also a need to develop new or improved dengue control approaches (2). In this paper, the situation of scientific research on dengue is analyzed for the developing country of Costa Rica. Although dengue has become the most important vector-borne disease in Costa Rica over the last decade, published scientific research dealing with the local situation is scarce (3). This could be due to various factors such as the historical and political context and limited financial and human resources. Filling this gap in Costa Rica and other developing countries would benefit local control programs and help efforts around the world to develop best practices for dengue prevention and control. Making this new knowledge broadly available could help improve the global dengue situation.

\section{DENGUE AND DENGUE HEMORRHAGIC FEVER}

A viral disease, dengue is a great global public health concern. It is endemic in more than 100 countries of Africa, Southeast Asia, the Eastern Mediterranean, the Western Pacific, and the Americas. Dengue causes more illness and death than any other arbovirus. Worldwide, there are approximately 2.5 billion people at risk of infection, and the World Health Organization (WHO) estimates that there are about 50 to 100 million cases per year $(4,5)$. Although dengue-like symptoms had been reported 
earlier, the first known pandemic of dengue-like illness began in 1779 (6). Infrequent but often large epidemics occurred from 1780 to 1940. Many tropical urban centers became endemic during this period, and epidemic dengue hemorrhagic fever (DHF) emerged in the 1950s as Asian cities became hyperendemic with co-circulating dengue serotypes (7).

The virus responsible for dengue fever and DHF belongs to the family Flaviviridae (the same family as the yellow fever virus), and four different viral serotypes exist: DEN-1, DEN-2, DEN-3, and DEN-4 (7). Infection with one dengue serotype provides immunity for years, but it does not protect against infection with the other serotypes $(4,6)$. After an infection, a person usually remains asymptomatic or develops self-limiting dengue fever characterized by sudden fever and such symptoms as headache, retroorbital pain, body and joint aches, weakness, and rash. Mild or severe hemorrhagic manifestations can also be present after a first infection, but this is less frequent. Dengue hemorrhagic fever, which is more common in children, can lead to shock from blood loss, and even death. It is generally accepted that having had a prior dengue infection increases the risk of developing DHF upon infection with a different serotype (6).

Dengue virus is transmitted to humans through the bite of infected mosquitoes, and these mosquitoes usually have acquired the virus by ingesting blood of infected and viremic humans (transovarial transmission is also possible). Aedes aegypti is considered the main vector, although other Aedes species, including Aedes albopictus, have been implicated in rural epidemics as well as some urban ones $(6,8)$. Aedes aegypti is a mosquito that lives in close association with humans in urban and suburban environments. The mosquito prefers to ingest human blood, and it breeds in artificial containers such as drums, buckets, tires, flower pots, and vases $(6,9-11)$. Therefore, the epidemiology of dengue is highly related to the biology of the mosquito vector and human behavior, as well as the environment and the virus itself.

Ae. aegypti and dengue have a worldwide distribution in the tropics (4), and the incidence has increased significantly over the past 25 years (12). In the Region of the Americas, highly effective control campaigns eliminated Ae. aegypti from most of Central and South America during the 1950s, but discontinuation of the control efforts led to reinfestation during the 1970s and 1980s, and the reemergence of dengue (6). Transport of containers (such as tires and water drums) that harbor mosquito larvae has promoted the introduction of the disease into new areas, and so has travel by infected individuals $(1,7,13)$. Globalization, population growth, and uncontrolled or unplanned urbanization (where inade- quate housing, water supply, and garbage collection services increase available larval habitats) have all been major factors influencing the current pandemic (14). These demographic and social changes, as well as a lack of effective mosquito control, have facilitated the spread and permanence of Ae. aegypti and dengue virus in many areas of the world (6).

There is no effective vaccine for dengue, so vector control is the main approach for control and prevention. Although insecticide spraying has been used extensively, larval source reduction (eliminating or cleaning water-filled containers that can harbor Ae. aegypti larvae) is considered the most effective way of reducing and controlling the mosquito populations (6). This control method has used vertical and community-based approaches. Most vertical approaches have been unsuccessful due to poor sustainability, and community-based approaches (with extensive health education and community outreach) have been only partially successful. The increasing spread and incidence of dengue suggests that the current vertical and community-based measures are generally ineffective, are inappropriate, or are being applied incorrectly (2).

Scientific interest in research on dengue has grown, and opportunities for investigators to obtain funds for that research have improved. Funding agencies, such as governments and international organizations, have increased the amount of money available for research in response to dengue's growing global incidence and impact on public health. The Special Program for Research and Training in Tropical Diseases (TDR), which is an independent global program of scientific collaboration cosponsored by the United Nations Children's Fund, the United Nations Development Program, the World Bank, and WHO, has classified dengue as an "emerging or uncontrolled disease," where research should be directed toward the "acquisition of new knowledge and design of new disease control tools and systems" (15). Currently, research supported by public sector funds is focused mainly on molecular epidemiology, immune pathophysiology, second-generation vaccine discovery, and new or improved approaches to vector control (16). According to the WHO/TDR Scientific Working Group on Insect Vectors and Human Health, vector control objectives could be rationalized by understanding the factors involved (vector, host, virus, environment) and their role in transmission dynamics at the local level (2).

\section{DENGUE AND SCIENTIFIC RESEARCH IN COSTA RICA}

Dengue is the most important vector-borne disease in Costa Rica, and Ae. aegypti is the mos- 
FIGURE 1. Number of dengue cases reported in Costa Rica, 1993 to 2005

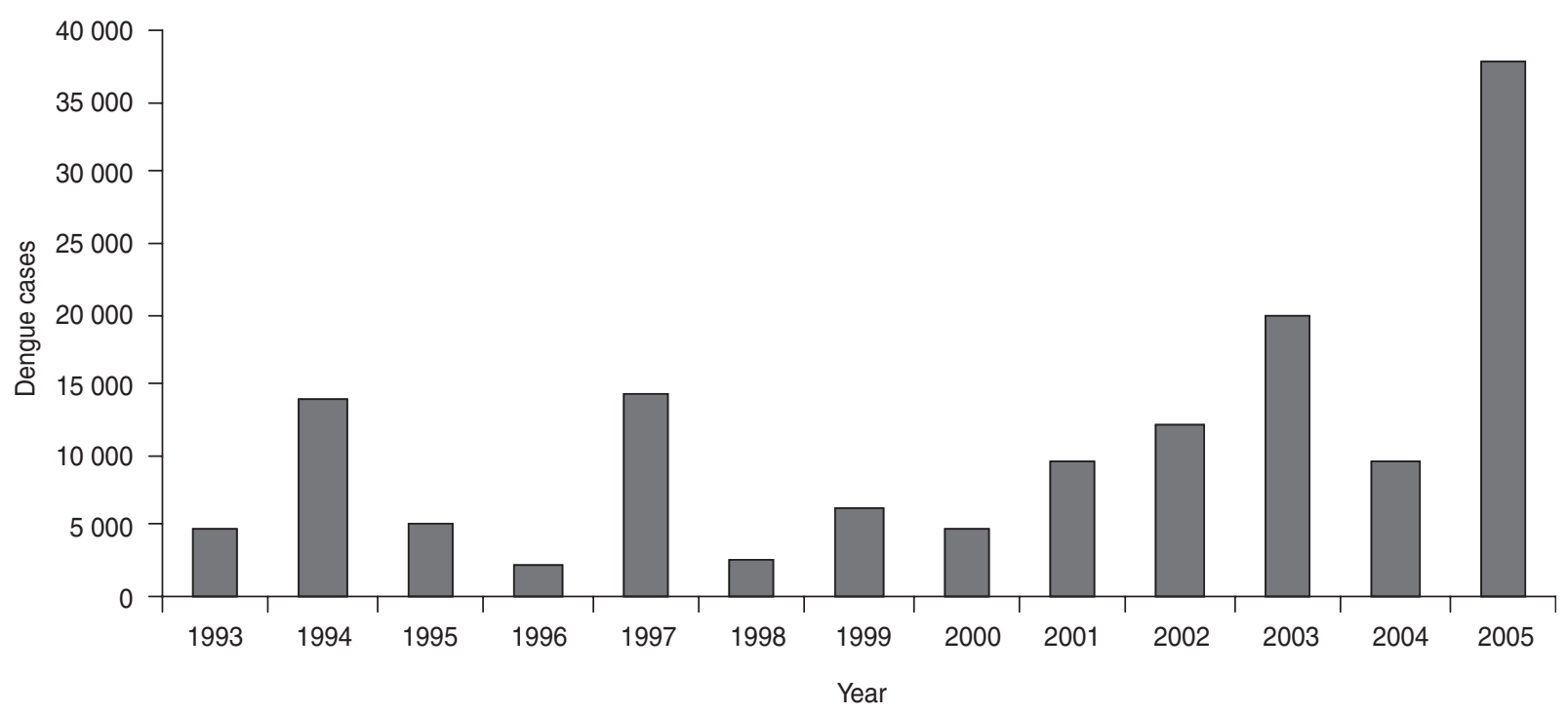

quito responsible for viral transmission. This mosquito species was eliminated from the country in 1960, but reinfestations occurred in some areas during the 1970s, and Ae. aegypti was reported throughout the country in 1993. After more than 30 years of absence, autochthonous cases of dengue fever were reported in the country at the end of 1993 (17). Since the reintroduction of Ae. aegypti in Costa Rica there have been more than 140000 cases reported (Figure 1) (18-21), and all four serotypes have been detected (22).

In Costa Rica the Ministry of Health $(\mathrm{MOH})$ is the entity that directs, conducts, regulates, and investigates health development, and the $\mathrm{MOH}$ is also in charge of health surveillance (23). Dengue control measures and guidelines are generally directed by the $\mathrm{MOH}$, and they include the use of insecticides and larvicides during epidemics, environmental care, house-to-house inspections, and educational campaigns urging community members to eliminate larval habitats and to protect themselves from mosquito bites (20). Associated with the $\mathrm{MOH}$ is the Instituto Costarricense de Investigación y Enseñanza en Nutrición y Salud (Costa Rican Institute for Research and Teaching on Nutrition and Health) (CRIRTNH). CRIRTNH is in charge of national research and education programs in nutrition and health, according to the national policy on nutrition and health (24). Another public institution that works closely with the $\mathrm{MOH}$ is the Caja Costarricense de Seguro Social (Costa Rican Social Security Fund) (CRSSF). An autonomous institution, the CRSSF is in charge of public health care services, social security, and basic pensions, and it also promotes research on and development of health care (25). In addition, the general organization of the national health sector encompass various ministries and institutions, including universities (specifically the health-related departments within the universities), the Instituto Nacional de Seguros (National Insurance Institute), the Instituto Costarricense de Acueductos y Alcantarillados (Costa Rican Water and Sewer Institute), and the private health sector (26).

Few studies have assessed the burden of dengue on a country's economy. Disability-adjusted life years (DALYs) have been estimated for dengue at approximately 427 DALYs per year per million population in Thailand (for 2001) (27), and 658 DALYs per year per million population in Puerto Rico (19841994) (28). This means that the losses from dengue are much greater than those estimated for DHF alone, and similar to those attributed to meningitis, hepatitis, or malaria in Latin America and the Caribbean (28). In Costa Rica, the CRSSF reported spending approximately US\$ 1.23 million (465 876441 Costa Rican colones) for dengue care during 2002 and US\$ 1.45 million (605 530103 colones) in 2003 (29). Given the number of dengue cases reported in each of those years, the CRSSF spent about US\$ 100 per case in 2002 and US\$ 74 per case in $2003(19,21)$.

According to a 2002 analysis of the health sector done by the $\mathrm{MOH}$, the overall importance of transmissible diseases has been declining in Costa Rica, but dengue has been one of the vector-borne diseases of increasing significance (26). The analysis recommended maintaining and improving surveillance systems, as well as performing epidemiologi- 
cal studies for implementation and evaluation of national interventions, policies, plans, and projects. In a national health policy for 2002-2006 that was produced by the Government of Costa Rica (30), HIV / AIDS and sexually transmitted diseases were the only infectious diseases for which specific policies were developed. However, policies on other infectious diseases were to be integrated into the other general strategies and policies. There was also a policy on "research that responds to established priorities based on the analysis of health conditions and needs of the health sector." The strategies set for this policy included the development of a strategic agenda for research on health, strengthening of the Consejo Nacional de Investigación en Salud (National Health Research Council), development of mechanisms that guarantee funding for health research that responds to health priorities, and integration of research information and results into the health information system. A national strategy for integrated dengue control and prevention in Costa Rica (31) that began in 2004 was intended to strengthen existing programs, reduce transmission, and develop a comprehensive surveillance system. The strategy specifically includes engaging in and collaborating on entomological, epidemiological, clinical, and social research activities focused on dengue.

\section{Scientific research related to dengue in Costa Rica}

Most scientific research in Costa Rica is carried out by public universities and their associated research centers and institutes. While there are many private universities in the country, they produce very little research, compared to the more researchoriented (and generally larger) public institutions. Health-related departments of public and private universities are official components of the national health sector in Costa Rica. These departments are responsible both for training professionals and technicians in the health fields and for developing research projects to strengthen and improve health (26). The public universities that are most closely associated with health research and that would generally be expected to engage in research on dengue are the Universidad Nacional (National University) and the Universidad de Costa Rica (University of Costa Rica). The University of Costa Rica is the largest public university in Costa Rica, and it is the university that does the most research in the country. For example, University of Costa Rica staff members wrote more than $50 \%$ of the scientific publications by Costa Rican authors cited in the Science Citation Index during the period of 1999-2001 (32).
Research in the area of biomedical sciences is well represented in Costa Rica, and the number of publications has been increasing in recent years (32). In addition to research done at public universities, biomedical research is carried out by the $\mathrm{MOH}$ (mainly through CRIRTNH), the CRSSF, and other independent research institutes such as the Instituto Nacional de Biodiversidad (National Institute of Biodiversity). The $\mathrm{MOH}, \mathrm{CRIRTNH}$, and CRSSF are responsible for many of the scientific publications in the health field. The CRIRTNH has specific research programs in infectious diseases (including dengue) and molecular techniques (including dengue diagnostic methods). The CRIRTNH is the national dengue reference center, and it provides laboratory confirmation for suspected dengue cases (33).

There are few scientific articles on dengue in Costa Rica. This is in spite of the country's capacity for conducting high-quality scientific research, the public health importance of dengue, and the different entities where research is under way or could be developed. This situation is even worse if only scientific research (with a specific methodology, results, and analysis) that has been published in peerreviewed journals is considered.

The lack of publications is evident when terms such as "Costa Rica" and "dengue" or "Costa Rica" and "Aedes aegypti" are used to search in PubMed, the biomedical journal literature search system of the National Library of Medicine of the National Institutes of Health of the United States. When we searched PubMed, we found only 11 relevant articles. Four of these 11 should not be considered original research pieces. One of the 4 was a general review, and 3 others were general descriptive reports carried in bulletins produced by either the Pan American Health Organization (PAHO) or WHO. Of the 7 original research papers, only the most recently published one (34) described the dengue situation in the country in some way (antibody detection in children). Of the remaining 6 publications, 2 of them only included blood samples from Costa Rica for diagnostic assays $(35,36)$, one used mosquito samples collected in Costa Rica for detecting insecticide resistance (37), one tested a species of copepods from Costa Rica for possible biological control (38), another evaluated insecticides for control (39), and the last one dealt with the presence of dengue in bats (40). Among the 11 publications, only the most recent one (34) included a first author affiliated with a Costa Rican institution. In the 11 pieces found in the PubMed search, there were no articles on public health or population-based epidemiological research, none with descriptive analyses of the vector situation in the country (or specific communities), none on testing for new control approaches, and none on the efficacy of current public health interventions in the country. 
Peer-reviewed health journals from Costa Rica and some other Latin American countries that are not included in PubMed can be searched through such other bibliographic databases as REVIST (articles from health journals from Costa Rica), SciELO (scientific journals from Latin America and the Caribbean), SciELO Costa Rica (scientific journals from Costa Rica), LILACS (Latin American and Caribbean literature on the health sciences), and IMBIOMED (a Mexican index of Latin American biomedical journals). However, these databases, which include many articles in languages other than English, are frequently overlooked by researchers and health professionals in developed countries (41). Searches in these databases would be expected to yield more scientific publications concerning dengue in Costa Rica, and, in fact, additional articles were found when we performed searches. However, when excluding the 11 pieces already found in the PubMed search, and including only publications in peer-reviewed journals, only 19 new pieces remained. Of these 19,6 of them were descriptive reports or literature reviews. Of the 13 other papers, 3 of them resulted from a project on biological control efforts using copepods in one community (42-44), and another 3 from an analysis of vector populations in one neighborhood $(11,45,46)$. Two were related to clinical symptoms and diagnostic criteria $(47,48), 2$ to effects of viral infection and the response in cells $(49,50)$, and the remaining 3 included epidemiological descriptions and surveillance evaluations (51-53). Therefore, given the results of the literature searches done in databases other than PubMed, it appears that there is some information that may be useful for control activities in Costa Rica, especially in terms of descriptive epidemiological analyses, the analysis of mosquito larval habitats, and the potential for biological control. However, there is still insufficient published original research that is widely available to the scientific community. There are few original research articles that have been published in peerreviewed journals. In addition, the articles that have been published show little diversity in terms of research topics. This is especially true for those areas related to epidemiology and public health, and the appropriateness and efficacy of current prevention and control interventions in Costa Rica.

Another source of scientific research in Costa Rica are students' university theses. Although the results of some theses are summarized and published in peer-reviewed journals, not all of them are. Complete theses are available in Costa Rica through the universities' libraries, but accessing them from other countries is more difficult, and these "unpublished" materials are generally not considered for further worldwide analysis and application.
Searches done via the Internet of the databases of the libraries of the University of Costa Rica and the National University yielded 10 theses that were directly related to original research on dengue (literature analyses and reviews were excluded). Four of the 10 were theses for a master's degree in epidemiology from the National University's Regional Graduate Program in Veterinary Tropical Sciences (Posgrado Regional en Ciencias Veterinarias Tropicales). Six of the 10 theses were from various programs of the University of Costa Rica (pediatrics, public health, microbiology, and nursing). The 10 theses included ones with specific evaluations and descriptions, clinical findings, epidemiological modeling, and surveillance strategies, as well as information on social organization and response, seroprevalence, and viral phylogenetics. This listing indicates the increasing interest in various areas of dengue research at these two public universities. However, the continuing dengue problem warrants further evaluation, additional research, and broader presentation of results to the international scientific community.

International organizations, such as WHO and PAHO as well as Costa Rican entities such as the $\mathrm{MOH}, \mathrm{CRIRTNH}$, and CRSSF, have published many documents on dengue, and they have dengue-related information on their Web sites. However, the $\mathrm{MOH}$ surveillance information is sometimes not updated for months. The Web sites of the WHO, PAHO, CRIRTNH, MOH, and CRSSF list various documents that can give an idea of the dengue problem in Costa Rica. In general, there are five types of documents: (1) guidelines for diagnosis, reporting, and control; (2) national programs and policies; (3) reports of surveillance and local situations; (4) reports of experiences from prevention and control activities; and (5) summaries and results of workshops. However, many of the documents are not available for downloading in full-text format. In addition, the majority of the documents cannot be considered valid scientific research. They do not have a specific initial hypothesis or objectives, a detailed methodology description, or a research results section. In addition, they have not gone through the final validation process of peer review by other scientists.

\section{Possible reasons for the gap in local scientific research}

The lack of scientific research on dengue in Costa Rica needs to be viewed in a national context in order to look for possible explanations. Among the possible reasons for the gap are these six: the historical context, limited human resources, limited 
financial resources, issues with data availability, and difficulties in collaboration. Each of these six will be briefly discussed in the paragraphs below.

Historical context. Dengue in Costa Rica reemerged relatively recently, in 1993, after being absent from the country for more than 30 years (17). At that time there was probably a lack of knowledge of dengue in the health field, including among scientists and public health officials at universities, research institutes, the $\mathrm{MOH}$, and the CRSSF. Moreover, many of those authorities may have considered the existing knowledge on this disease system to be adequate for developing effective control and prevention programs for the country. This could have led to a slow response in new local scientific research. In addition, existing research groups already had defined areas of interest in other diseases that were more relevant while dengue was absent. Many of these research group scientists are still active, and they have continued with their areas of research, thus influencing the path that new, younger scientists follow.

Limited human resources. The human resources in the $\mathrm{MOH}$, the CRSSF, and other public institutions are generally limited, so those persons have little or no time available to conduct research. Outside CRIRTNH, there are also few real incentives and little support for research efforts, and public institutions must prioritize their activities with the time and personnel that they have available. In addition, the fact that dengue's reappearance is relatively recent means that there are not many scientists with long careers in dengue research. There are now no scientists, academicians, or health professionals in the country who stand out as established dengue experts, such as by having published more than five original scientific research articles on dengue or Ae. aegypti, and with at least one publication in an international journal.

Limited financial resources. It is estimated that the countries of Latin America and the Caribbean account for only around $2 \%$ of the worldwide funding and scientific output in the health field (54). Local public funding for research is generally limited in developing countries, and this is the case in Costa Rica. Funding in the MOH and CRSSF does not include specific funds for conducting research and writing publications, and activities must be prioritized within their limited budgets. Funding in universities is available specifically for research, but it is still limited and generally goes to research institutes and centers, or to a small number of modest, low-budget projects (in many cases with a budget of less than US\$1000 per year, excluding salaries).
Issues with data availability. Health statistics and surveillance data are handled by the CRSSF and the $\mathrm{MOH}$, and that information is usually made available to other countries through bulletins and Web sites. Data on the Web sites is sometimes only updated every few months, so recent data are generally obtained directly from the institutions. Obtaining the data may be difficult for international and even Costa Rican scientists who are not working directly with those institutions. Data on specific individual community control projects and activities is even harder to obtain.

Difficulties in collaborating on research. There are limited research collaborations between the institutions that could be involved in scientific research on dengue in Costa Rica. However, research collaborations could contribute to establishing national priorities to guide research in this specific field. In developing countries, $\mathrm{MOH}$ staff members are sometimes asked by researchers from other institutions (from the same country or other countries) to assist with scientific studies, but those staff members are rarely notified about the resulting publications or credited as coauthors in the resulting articles (55). In addition, although many research activities require effort and dedication, the public health sector perceives that there are few measurable direct benefits for the health of people in general (55). These issues can determine whether the $\mathrm{MOH}$ or other governmental agencies are interested in collaborating with other organizations and individuals on research activities.

Limited publication of results in scientific journals. It is possible that more quality research concerning dengue in Costa Rica is being conducted, but the results are not being published in peerreviewed journals. In fact, the 2004 final report on the national strategy for integrated dengue control and prevention in Costa Rica (31) recommended participation in relevant research activities. However, researchers may not have enough time or incentives to write scientific papers, or they may be more interested in applying the research results than in preparing them for formal publication. In public health institutions, the priority might be to take action based on experiences or results, so there are not many scientific articles resulting from their work. Another possible reason for not publishing results may be that some Costa Rican public health researchers fear that other researchers, from Costa Rica or other countries, will criticize the methods or the validity of the results presented in any publications. In addition, written and televised news reports frequently inform the public about the situation with dengue, with $\mathrm{MOH}$ and/or CRSSF offi- 
cials being interviewed or providing information. Therefore, those officials may consider such news reports and interviews, along with bulletins and reports, as being sufficient for keeping the public up to date. However, if researchers do not publish scientific papers about the situation in Costa Rica, the country's situation does not receive serious international feedback.

\section{LESSONS FROM OTHER COUNTRIES IN THE REGION OF THE AMERICAS}

From performing literature searches for other countries of Central America, we believe that the situation with respect to scientific publishing on dengue in those countries is much like the situation in Costa Rica. However, there are certain nations in Latin America and the Caribbean that have much more experience with dengue research. Two small countries that exemplify this are Cuba and Trinidad and Tobago.

The history of dengue in Cuba is somewhat different from that in Costa Rica. Cuba suffered very severe epidemics of dengue fever and DHF before the 1990s. There was an epidemic in 1977, where approximately $45 \%$ of the population was infected with DEN-1. There was an epidemic in 1981, with the DEN-2 serotype and many cases of DHF being reported. After that, dengue was effectively controlled until 1997 (56).

Cuba has a long history of research on dengue, mainly due to the Pedro Kourí Institute of Tropical Medicine (of the Cuban Ministry of Health). This institute contains several PAHO/ WHO collaborating centers, including the PAHO/ WHO Collaborating Center for the Study for Virology and the PAHO/WHO Collaborating Center for the Study and Control of Dengue.

A search for documents related to dengue and Cuba in PubMed yielded 99 items, with 59 of them being published in 1993 or more recently. A search in LILACS found 75 items. There were many reviews, as well as papers on such areas as descriptive epidemiology, immunology, diagnostics, vector biology, control, community organization, and pathology and immunopathology. In addition, a search of the WHO library located 13 WHO publications, most of which reviewed and analyzed the dengue situation, experiences, and control programs by using Cuban publications.

Cuban publications have provided scientific evidence for developing guidelines on dengue and DHF control, as well as for diagnosis and understanding dengue immunopathology. Cuba is one of the very few places where source reduction efforts have had documented success (57), and there is also published evidence for effective intersectoral coordination and control activities (58). This research from Cuba is made available in the scientific literature, and has helped in Cuba and around the world to better understand this disease system and efforts for its control. The information coming from Cuba has also been an important part of the scientific evidence that has been used to develop WHO guidelines.

Trinidad and Tobago was declared free of $A e$. aegypti in 1960, but the island of Trinidad became reinfested very soon after that. However, the island of Tobago remained free of the mosquito until 1981 (59). Dengue incidence increased during the 1980 s and 1990s, and a major outbreak occurred in 1998 (60). A basic search for scientific articles containing the terms "dengue" and "Trinidad" or "Aedes" and "Trinidad" in PubMed yielded 75 publications (with 33 of them since 1993). A similar search in MedCarib (Caribbean health sciences literature) also produced 75 publications. Most of the papers were related to dengue epidemiology and vector biology, and they included such topics as ecology, dengue transmission dynamics, population genetics, insecticide resistance, epidemiology, surveillance methods, control approaches and activities, and virology. It is worth noting that many of the articles were linked to the same researchers in Trinidad and Tobago, whose efforts have included collaborations with various international institutions and organizations.

Much of the knowledge on Ae. aegypti behavior and dengue transmission in the Americas has come from studies in Trinidad and Tobago. Vector control activities must take into account the biology and ecology of the mosquito vector, and scientific evidence is crucial for control approaches. For example, research in Trinidad and Tobago has helped to determine local types of breeding sites that should be targeted for control, thresholds for dengue transmission (which help define vector control targets) (57), and new or more adequate methods for entomological surveillance and control (10, $61,62)$. The results from these and other studies of Trinidad and Tobago have been used to support many publications and reviews that are relevant to public health around the world.

Costa Rica could learn from Cuba and Trinidad and Tobago, considering how their research has been critical for the development of local and global dengue control and prevention strategies. The articles published from research conducted in Cuba and Trinidad and Tobago are a great example of interdisciplinary research and intersectoral collaboration. There are currently PAHO and $\mathrm{WHO}$ control guidelines that are consistent with this international research, but the growing incidence of dengue in Latin America and the Ca- 
ribbean suggests that local factors also need to be studied rigorously. It is not enough to simply follow approaches that have been established in other geographical areas. At the local level, some prevention and control methods may be more effective than others, depending on the political, social, cultural, educational, environmental, and economical context. Therefore, control activities that are based on scientific evidence need to be adapted for different communities, countries, and world regions.

\section{POSSIBLE BENEFITS AND POSSIBLE DETRIMENTS FROM LOCAL SCIENTIFIC RESEARCH}

Benefits could come from local scientific research on dengue if that research produced a better understanding of the diseases system, including the local determinants of human and vector behavior, disease severity, and changing dengue epidemiology. In addition, interdisciplinary research could generate evidence concerning other dengue-related issues that are usually not considered during "traditional" infectious disease research. For example, interdisciplinary approaches could bring to light the true impact of control activities in communities, the attitudes of people toward the disease, and the attitudes of people toward control programs. The new information could improve current local efforts. Further, this research could have an impact on both the country where the research was done and on other nations in the same world region. Vector control objectives could be rationalized by understanding the factors involved and their role at the local level (2). Moreover, publication of information about specific experiences would make it possible to evaluate those experiences, and the experiences could provide useful insights for similar control programs in other countries.

Nevertheless, an increased but unbalanced focus on scientific research and publication on dengue in Costa Rica could harm other health programs in the country by decreasing resources available for other health areas and other diseases. Research might not be widely accepted politically by Government officials if the publication of results promoted public criticism of Government-run institutions. This criticism might be a consequence of unexpected "negative" results found while investigating such things as ongoing control programs and public health services administered by the Government. Criticism might also come from members of the general public who thought that resources were not being handled properly. This could happen if the results of publicly funded research did not directly or immediately improve the health situation or have relevance for current health policies and programs. Also, if priority areas were not clearly defined, specific areas of research that should be national or global priorities might be ignored, or there might be redundancy among various research activities, with a resulting waste of human and financial resources.

\section{CONCLUSIONS AND RECOMMENDATIONS}

As in other developing tropical countries, dengue has become a serious health problem in Costa Rica, and the situation does not seem to be improving. Moreover, published scientific research related to dengue in Costa Rica is scarce, especially concerning scientific evidence for local risk factors and control activities. More research is needed to generate scientific evidence that will support control programs. Research is also needed in the multidisciplinary fields of knowledge that are related to dengue. This research will serve to identify local risk factors and to determine how the behavior of human, vector, and viral populations-and the interactions between them and the environment-are affecting the disease system. Also, scientific evaluations of current control activities, their true impact on dengue transmission, and the risk for future outbreaks would enhance control and prevention efforts. In turn, this would improve strategies at the community, country, and global levels, by making the results available through scientific publications.

Health officials, scientists, and research groups in Costa Rica need to strengthen their intercommunications and promote discussion and exchange of ideas concerning the dengue situation. As has been outlined in the national health policy for 2002-2006 (30) and the national strategy for integrated dengue control and prevention (31), it is important for the country to set priorities in specific areas of dengue research and to plan for the most relevant investigations. Multidisciplinary and intersectoral participation would improve the research, as dengue epidemiology is closely related to human behavior, the environment, the vector, and the virus. Working within the framework of the scientific research activities and priorities, the collaborating sectors and institutions would need to address the social, political, economical, cultural, and environmental contexts.

Increasing the research collaborations between the public health sector and the academic/ research sector in Costa Rica would be beneficial for all those involved. It could optimize research funds and human and technological resources (63), as well as reduce redundant research efforts. Increased collaboration could also help bridge the gap that often exists between scientific results and 
public health activities, as well as help promote the acceptance of local scientific evidence and its application in the community (63). Collaboration between local institutions and international entities could also be promoted. This would increase research resources, training opportunities for scientists, and possibilities for comparing the dengue situation in Costa Rica with that of other countries.

Building capacity and conducting more training in research areas related to dengue is an important effort that could be explored further by Government institutions and nongovernmental entities in Costa Rica. This process could be assisted through collaborations with international organizations, academic institutions, and research centers. Scientific expertise needs to be developed to carry out and promote quality health research, and building this capacity is an integral part of the health research systems at the national and global levels (64). The growth in expertise could result in more resources being allocated for dengue research, as well as national and international collaborations. Building the interdisciplinary research capacity within the country's institutions is essential. The country needs dengue research experts in multiple disciplines to produce high-quality research on such topics as virology, entomology, epidemiology, public health, social sciences, and communications.

While health authorities in Costa Rica realize the importance of intersectoral and multidisciplinary investigations of dengue (31), more efforts are needed to promote timely publication of the research results in scientific journals. This would allow the country to share its knowledge of new approaches for control activities and to receive feedback from fellow scientists. The scientific evidence would be useful in the global efforts to understand dengue and why control methods do not seem effective in many areas of the world. The information would also provide different, Costa Rican (Central American) perspectives to consider when analyzing evidence-based global guidelines from organizations such as WHO and when assessing guidelines for the Region of the Americas from PAHO.

The rising incidence of dengue in Costa Rica and in other areas of the world shows the need for many different efforts to fight this disease. These efforts should include filling the gaps in local scientific research on dengue. However, this cannot be done without collaboration among the various sectors related to the health field, multidisciplinary approaches to understanding and solving disease problems, and the political will to support scientific research activities.

Acknowledgements. Support was provided by Grant Number P20 RR020770-02 from the Na- tional Center for Research Resources (NCRR), a component of the National Institutes of Health (NIH) of the United States of America. The contents of this article are solely the responsibility of the authors, and do not necessarily represent the official view of NCRR or NIH.

\section{SINOPSIS}

\section{Dengue en Costa Rica: la brecha en la investigación científica local}

El dengue es una enfermedad de gran importancia a escala mundial. Los esfuerzos para su control en la mayoría de las regiones del mundo no han logrado detener el aumento en su incidencia, y se fomenta la investigación científica para contribuir a desarrollar nuevos enfoques de control basados en la evidencia científica o a mejorar los existentes. Enfermedad recientemente reemergente en Costa Rica, el dengue se ha convertido en un grave problema de salud en ese país. A pesar de esta crítica situación, se dispone de pocas publicaciones científicas sobre dengue en Costa Rica. En una búsqueda realizada en la base de datos PubMed se encontraron solo 11 artículos, mientras que en varias bases de datos bibliográficas centradas en Costa Rica y otros países de América Latina se hallaron 19 artículos más. Además, se encontraron 10 tesis relacionadas con el dengue realizadas en universidades costarricenses. Por lo tanto, son pocos los artículos científicos originales publicados sobre este tema en revistas científicas arbitradas, especialmente en aspectos vinculados con la epidemiología, la salud pública y la idoneidad y eficacia de las intervenciones en marcha. Esta brecha en las investigaciones puede deberse a diversos factores, como el contexto histórico y político, insuficientes recursos financieros y humanos, deficiencias en la colaboración entre las instituciones y dificultades para disponer de los datos. Costa Rica puede aprender de la experiencia de otros países de la Región de las Américas (como Cuba y Trinidad y Tobago), donde se ha investigado mucho más sobre dengue. Las investigaciones de esos dos países han aportado evidencias cruciales para el desarrollo de estrategias locales y generales dirigidas al control y la prevención del dengue. En dependencia del contexto local, algunos métodos de control pueden ser más eficaces que otros, por lo que las acciones basadas en la evidencia deben adaptarse para las diferentes regiones del mundo, países y comunidades. La producción científica en Costa Rica puede aumentar si se incrementa la colaboración interinstitucional en investigaciones, se realizan más entrenamientos, se eleva la capacidad investigativa y se estimula la publicación oportuna de los resultados investigativos. Comenzar a acortar la brecha relacionada con las investigaciones sobre el dengue en los países en desarrollo sería un paso importante hacia el control mundial de esta enfermedad.

Palabras clave: dengue, investigación, investigación biomédica, países en desarrollo, Costa Rica. 


\section{REFERENCES}

1. Harrus S, Baneth G. Drivers for the emergence and re-emergence of vectorborne protozoal and bacterial diseases. Int J Parasitol. 2005;35(11-12):1309-18.

2. Scientific Working Group. Report on insect vectors and human health. Geneva: World Health Organization/Special Programme for Research and Training in Tropical Diseases; 2003. (TDR/SWG/ VEC/03.1).

3. Recio-Domingo M, Ruiz-Díaz JI, Figueroa-Córdoba D, Hernández-Chavarría F. Epidemiología del dengue en el cantón de Esparza, Puntarenas, Costa Rica 1997-2002. Rev Costarric Cienc Med. 2002;23(3-4):141-6.

4. World Health Organization. Dengue and dengue hemorrhagic fever. Available from: http://www.who.int/ media centre/factsheets/fs117/en/ [Web site]. Accessed 14 September 2006.

5. Pan American Health Organization/ World Health Organization, Rockefeller Foundation, Pediatric Dengue Vaccine Initiative. Report: workshop on dengue burden studies. Available from: http:// www.paho.org/English/AD/DPC/CD/ burden-dengue-11-2002.htm [Web site]. Accessed 14 September 2006.

6. Gubler DJ. Dengue and dengue hemorrhagic fever. Clin Microbiol Rev. 1998; 11(3):480-96.

7. Gubler DJ. The changing epidemiology of yellow fever and dengue, 1900 to 2003: full circle? Comp Immun Microbiol Infect Dis. 2004;27(5):319-30.

8. Effler PV, Pang L, Kitsutani P, Vorndam V, Nakata M, Ayers T, et al. Dengue fever, Hawaii, 2001-2002. Emerg Infect Dis. 2005;11(5):742-9.

9. Service MW. Importance of ecology in Aedes aegypti control. Southeast Asian J Trop Med Public Health. 1992;23(4): 681-9.

10. Focks DA, Chadee DD. Pupal survey: an epidemiologically significant surveillance method for Aedes aegypti: an example using data from Trinidad. Am J Trop Med Hyg. 1997;56(2):159-67.

11. Calderón-Arguedas O, Troyo A, Solano ME. Caracterización de los sitios de multiplicación de Aedes aegypti (Diptera: Culicidae) en el caserío "La Carpio", San José, Costa Rica durante la estación seca del año 2003. Rev Biomed. 2004;15(2): 73-9.

12. Gubler DJ. The emergence of epidemic dengue fever and dengue hemorrhagic fever in the Americas: a case of failed public health policy [editorial]. Rev Panam Salud Publica. 2005;17(4):221-4.

13. Lounibos LP. Invasion by insect vectors of human disease. Annu Rev Entomol. 2002:47:233-66.

14. Kuno G. Review of the factors modulating dengue transmission. Epidemiol Rev. 1995;17(2):321-35.

15. Special Programme for Research and Training in Tropical Diseases. TDR diseases. Available from: http://www. who.int/tdr/diseases / default.htm [Web site]. Accessed 14 September 2006

16. Special Programme for Research and Training in Tropical Diseases. Strategic direction for research. Available from: http://www.who.int/tdr/diseases/ dengue/direction.htm [Web site]. Accessed 14 September 2006.

17. World Health Organization. Outbreak of classic dengue, Costa Rica. Wkly Epidemiol Rec. 1994;69(12):85-6.

18. Guzmán MG, Huelva G, Saenz E, Quiroz E, de los Reyes J, Balmaseda A, et al. Reintroducción del dengue 3 en las Américas 1994-1996. Arch Venez Med Trop. 1998;2:8-19.

19. Costa Rica, Ministerio de Salud. Vigilancia epidemiológica. Available from: http://www.ministeriodesalud.go.cr/ estavigiepi.htm [Web site]. Accessed 15 May 2006.

20. Costa Rica, Ministerio de Salud, Vigilancia de la Salud. Dengue. Available from: http://www.ministeriodesalud.go.cr/ dirvigil/dengue.htm [Web site]. Accessed 18 November 2005.

21. Caja Costarricense de Seguro Social. Sitio Institucional de Lucha contra el Dengue. Total de casos de dengue clásico atendidos 1993-2004. Available from: http://www.ccss.sa.cr/geradm/ dircom/elseguro/dengue/casos_1993. html [Web site]. Accessed 14 September 2006.

22. Pan American Health Organization. Dengue in Central America: the epidemics of 2000. Epidemiol Bull. 2000; 21(4):4-8.

23. Costa Rica, Ministerio de Salud. Estructura del Ministerio de Salud. Available from: http://www.ministeriodesalud. go.cr/estructura.htm [Web site]. Accessed 14 September 2006.

24. Instituto Costarricense de Investigación y Enseñanza en Nutrición y Salud. Misión. Available from: http://www.net salud.sa.cr/ms/inciensa/mision.htm [Web site]. Accessed 15 May 2006.

25. Caja Costarricense de Seguro Social. Misión institucional. Available from: http://www.ccss.sa.cr/ccssvm.htm [Web site]. Accessed 14 September 2006.

26. Costa Rica, Ministerio de Salud. Análisis sectorial de salud. Sección 1. San José: Ministerio de Salud; 2002

27. Clark DE, Mammen Jr. MP, Nisalak A, Puthimethee V, Endy TP. Economic impact of dengue fever/dengue hemorrhagic fever in Thailand at the family and population levels. Am J Trop Med Hyg. 2005;72(6):786-91.

28. Meltzer MI, Rigau-Pérez JG, Clark GG, Reiter P, Gubler DJ. Using disabilityadjusted life years to assess the economic impact of dengue in Puerto Rico: 1984-1994. Am J Trop Med Hyg. 1998; 59(2):265-71.

29. Caja Costarricense de Seguro Social. Sitio Institucional de Lucha contra el
Dengue. Costo total de atención del dengue CCSS: 1999-2002. Available from: http://www.netsalud.sa.cr/ms/ inciensa/mision.htm [Web site]. Accessed 14 September 2006.

30. República de Costa Rica. Política nacional de salud 2002-2006. San José: República de Costa Rica; 2003.

31. Ministerio de Salud, Caja Costarricense de Seguro Social, Instituto Costarricense de Investigación y Enseñanza en Nutrición y Salud, Banco Interamericano de Desarrollo, Organización Panamericana de la Salud, Organización Mundial de la Salud. Informe final. Estrategia nacional de gestión integrada de prevención y control del dengue en Costa Rica. Available from: http://www.cor.ops-oms. org/TextoCompleto/documentos/EGI $\% 20$ Costa $\% 20$ Rica $\% 20$ DOC $\% 20$ OFI $\% 20$ COMPLETO.doc [Web site]. Accessed 14 September 2006.

32. Lomomte B, Ainsworth S. Publicaciones científicas de Costa Rica en el Science Citation Index: análisis bibliométricos del trienio 1999-2001. Rev Biol Trop. 2002; 50(3-4):951-62

33. Instituto Costarricense de Investigación y Enseñanza en Nutrición y Salud. Campos de acción. Available from: http:// www.netsalud.sa.cr/ms/inciensa/ campos.htm [Web site]. Accessed 15 May 2006.

34. Iturrino-Monge $\mathrm{R}$, Avila-Agüero $\mathrm{ML}$ Avila-Agüero $\mathrm{CR}$, Moya-Moya $\mathrm{T}$, Cañas-Coto A, Camacho-Badilla K, et al. Seroprevalence of dengue virus antibodies in asymptomatic Costa Rican children, 2002-2003: a pilot study. Rev Panam Salud Publica. 2006;20(1):39-43.

35. Delgado I, Vázquez S, Bravo JR, Guzmán MG. Predicción del serotipo del virus del dengue mediante la respuesta de anticuerpos IgM. Rev Cubana Med Trop. 2002;54(2):113-7.

36. Vázquez S, Sáenz E, Huelva G, González A, Kourí G, Guzmán M. Detección de IgM contra el virus del dengue en sangre entera absorbida en papel de filtro. Rev Panam Salud Publica. 1998;3(3): 174-8.

37. Coto MM, Lazcano JA, de Fernandez DM, Soca A. Malathion resistance in Aedes aegypti and Culex quinquefasciatus after its use in Aedes aegypti control programs. J Am Mosq Control Assoc. 2000; 16(4):324-30.

38. Schaper S. Evaluation of Costa Rican copepods (Crustacea: Eudecapoda) for larval Aedes aegypti control with special reference to Mesocyclops thermocyclopoides. J Am Mosq Control Assoc. 1999;15(4): 510-9.

39. Perich MJ, Rocha NO, Castro AL, Alfaro $\mathrm{AW}$, Platt KB, Solano T, et al. Evaluation of the efficacy of lambda-cyhalothrin applied by three spray application methods for emergency control of Aedes aegypti in Costa Rica. J Am Mosq Control Assoc. 2003;19(1):58-62. 
40. Platt KB, Mangiafico JA, Rocha OJ, Zaldivar ME, Mora J, Trueba G, et al. Detection of dengue virus neutralizing antibodies in bats from Costa Rica and Ecuador. J Med Entomol. 2000;37(6): 965-7.

41. Clark OA, Castro AA. Searching the Literatura Latino Americana e do Caribe em Ciências da Saúde (LILACS) database improves systematic reviews. Int J Epidemiol. 2002;31(1):112-4.

42. Schaper S, Hernández F, Soto L. La lucha contra el dengue: control biológico de larvas de Aedes aegypti empleando Mesocyclops thermocyclopoides (Crustacea). Rev Costarric Cienc Med. 1998; 19(1-2):119-25.

43. Soto L, Shaper S, Angulo L, Hernández F. Mesocyclops thermocyclopoides y el control biológico de Aedes: ejemplo de un plan de acción comunitaria en Chacarita, Puntarenas. Rev Costarric Cienc Med. 1999;20(1-2):45-50.

44. Cordero-Conejo AC, Sandí-Nogueral F, Mejías-Fonseca G, Silva-Silva RA, Campos-Rodríguez MV, Soto L, et al. Reseña de una experiencia de promoción de la salud y lucha contra el dengue utilizando el control biológico, en escuelas de Chacarita, Puntarenas, Costa Rica. Rev Costarric Salud Publica. 2000;9(17): 20-5.

45. Calderón-Arguedas O, Troyo A, Solano ME. Diversidad larval de mosquitos (Diptera: Culicidae) en contenedores artificiales procedentes de una comunidad urbana de San José, Costa Rica. Parasitol Latinoam. 2004;59(3-4):132-6.

46. Calderón-Arguedas O, Solano ME, Troyo A. Sitios potenciales para la multiplicación de Aedes aegypti (Diptera: Culicidae) en relación con las características de las viviendas de la comunidad "La Carpio", San José, Costa Rica, durante la estación seca de 2003. Rev Costarric Salud Publica. 2003;12(23):22-30.

47. Suárez-Mastache G. Evolución clínico patológica de los pacientes pediátri- cos manejados en la unidad de dengue del Hospital Monseñor Sanabria de Puntarenas. Acta Pediatr Costarric. 1999; 1(13):33-8.

48. Sáenz E, Maranda L, González L. Adecuación de la definición de casos sospechosos de dengue, basado en la asociación de síntomas y signos según los registros médicos, Costa Rica, 1998. Rev Costarr Cienc Med. 2001;22(3-4):131-40.

49. Disla ME, Hernández F, Hun L. Alteraciones ultraestructurales inducidas por virus dengue en cultivos celulares. Rev Costarric Cienc Med. 1996;17(1):17-22.

50. Moya J, Hun L, Piza M. Dengue y dengue hemorrágico una enfermedad causada por disfunción de macrófago. Acta Med Costarric. 1996;1(38):26-30.

51. Alvarado-Brown A, Rivera-Valdivia F, Valladares-Bermúdez L, Rivera-Valdivia A, López-Casal G. Estudio de la epidemia del dengue en las comunidades bananeras de la Región Huetar Atlántica. Rev Med Costa Rica Centroam. 2005; 72(573):175-8.

52. Recio-Domingo M, Ferrín-Díaz JI, Figueroa-Cordova D, HernándezChavarría F. Epidemiología del dengue en el Cantón de Esparza, Puntarenas, Costa Rica 1997-2002. Rev Costarr Cienc Med. 2002;23(3-4):141-6.

53. Sáenz E, Maranda L, Piza J, González L, Achoy R. Evaluación del sistema de vigilancia epidemiológico del dengue utilizando como indicador la aplicación de la definición de caso sospechoso, Costa Rica 1998. Rev Costarr Cienc Med. 2001; 22(3-4):117-29.

54. Noronha J, Jouval Jr. H, Machado C. Public health in Latin America. In: Beaglehole R, ed. Global public health: a new era. New York: Oxford University Press; 2003. Pp. 120-34.

55. Basch PF. Textbook of international health. 2nd ed. New York: Oxford University Press; 1999.
56. Kouri G, Guzmán MG, Valdés L, Carbonel I, del Rosario D, Vazquez S, et al. Reemergence of dengue in Cuba: a 1997 epidemic in Santiago de Cuba. Emerg Infect Dis. 1998;4(1):89-92.

57. Focks DA, Brenner RJ, Hayes J, Daniels E. Transmission thresholds for dengue in terms of Aedes aegypti pupae per person with discussion of their utility in source reduction efforts. Am J Trop Med Hyg. 2000;62(1):11-8.

58. Sanchez L, Perez D, Pérez T, Sosa T, Cruz G, Kouri G, et al. Intersectoral coordination in Aedes aegypti control. A pilot project in Havana City, Cuba. Trop Med Int Health. 2005;10(1):82-91.

59. Chadee DD. Surveillance for the dengue vector Aedes aegypti in Tobago, West Indies. J Am Mosq Control Assoc. 2003; 19(3):199-205.

60. Chadee DD, Williams FLR, Kitron UD. Epidemiology of dengue fever in Trinidad, West Indies: the outbreak of 1998. Ann Trop Med Parasitol. 2004; 98(3):305-12.

61. Focks DA. A review of entomological sampling methods and indicators for dengue vectors. Geneva: World Health Organization/Special Programme for Research and Training in Tropical Diseases; 2003. (TDR/ IDE/Den/03.1).

62. Chadee DD. Key premises, a guide to Aedes aegypti (Diptera: Culicidae) surveillance and control. Bull Entomol Res. 2004;94(3):201-7.

63. Troyo A. The academic sector and its role in the regional initiative: the University of Costa Rica's experience. Available from: http://www.paho. org/English/AD/DPC/CD/lymph filariasis. pdf [Web site]. Accessed 14 September 2006.

64. Lansang MA, Dennis R. Building capacity in health research in developing countries. Bull World Health Organ. 2004;82(10):764-70 